\title{
Meningitis following a combined spinal- epidural technique in a labouring term parturient
}

\begin{abstract}
Purpose: To report a case of probable bacterial meningitis in a parturient who received a combined spinal-epidural (CSE) technique for labour analgesia.

Clinical Features: A 28-yr-old GIP0 at 40 wk gestational age presented in labour and requested analgesia. A CSE technique was used to inject a mixture of fentanyl $25 \mu \mathrm{g}$ and bupivacaine $2.5 \mathrm{mg}$ into the subarachnoid space following which a catheter was inserted into the epidural space. Sixteen hours after delivery her body temperature increased to $38.7^{\circ} \mathrm{C}$ and she complained of a non-positional frontal headache. This was associated with chills, photophobia, and mild nuchal rigidity. Diagnostic lumbar puncture revealed cloudy cerebrospinal fluid (CSF) with increased polymorphonuclear (PMN) white cell count and increased protein and decreased glucose concentrations. Peripheral blood cytology also showed an increased leukocyte count with a shift to the left. Immediate treatment with antibiotics was instituted and the patient rapidly recovered without sequelae.

Conclusions: Meningitis may occur, albeit rarely, with any neuraxial blocks including CSE techniques. Early diagnosis
\end{abstract}

\section{Key words}

ANAESTHETIC TECHNIQUES: regional: combined spinalepidural;

ANAESTHETICS, LOCAL: bupivacaine;

ANAESTHETICS, INTRAVENOUS: fentanyl;

COMPLICATIONS: neurological.

From the Departments of Anesthesiology and Critical Care Medicine, University of Pittsburgh, School of Medicine, and *Allegheny General Hospital, 320 East North Ave., Pittsburgh, PA 15212.

Work performed at: Magee-Womens Hospital, 300 Halket Street, Pittsburgh, PA 15213

Address correspondence to: Dr. Martin Cascio, Department of Anesthesiology, Magee-Womens Hospital, 300 Halket Street, Pittsburgh, PA 15213.

Accepted for publication 17 December, 1995. and appropriate antibiotic therapy are important in preventing serious neurological sequelae.

Objectif: Rapporter un cas de méningite bactérienne chez une parturiente qui a reçu une technique combinée spinale-épidurale (CSE) pour l'analgésie du travail.

Caractéristiques cliniques: Une femme de 28 ans G1P0 se présente en travail à la quarantième semaine de gestation et souhaite de l'analgésie. Une technique CSE est utilisée pour l'injection d'un mélange de fentanyl 0,25 $\mu \mathrm{g}$ et de bupivacaine $2,5 \mathrm{mg}$ dans l'espace sous-archnoïdien et un cathêter est installé dans l'espace épidural. Seize heures après l'accouchement, sa température monte à $38,7^{\circ} \mathrm{C}$, et elle se plaint d'une céphalée sans rapport avec sa position. Cette céphalée s'accompagne de frissons et d'une légère rigidité de la nuque. Une ponction lombaire diagnostique met en évidence un liquide céphalo-rachidien trouble avec augmentation des granulocytes, des protéines et une baisse du glucose. Une cytologie sanguine montre une hyperleucocytose avec déviation vers la gauche. Un traitement aux antibiotiques est débuté immédiatement et la patiente récupère sans séquelles.

Conclusions: Bien que rare, une méningite peut survenir avec les blocs médullaires. Un diagnostic précoce et l'antibiothérapie peuvent en prévenir les séquelles neurologiques graves.

Meningitis is a rare but serious complication of spinal and epidural anaesthesia. ${ }^{1-3}$ Both aseptic and bacterial meningitis have occurred after spinal anaesthesia.1,3 Combined spinal-epidural technique is a newer technique for providing labour analgesia. It has been shown to be a safe and effective in providing labour analgesia. Recently, two cases of meningitis, one aseptic, and one bacterial, were reported to have occurred following combined spinal epidural (CSE) for labour analgesia. ${ }^{4}$ We report a case of meningitis following a CSE technique for labour analgesia in a parturient in whom no contributing bacterial pathogen could be isolated, but cerebrospinal fluid (CSF) studies indicated a bacterial 
source of the meningitis. Immediate treatment with antibiotics was instituted and the patient rapidly recovered without sequelae.

\section{Clinical report}

A 28-yr-old G1P0 at 40 wk gestational age presented in labour and requested analgesia. Her past medical history was unremarkable except for a history of glucose intolerance treated with diet. At the time of admission, she denied any recent history of upper respiratory or urinary tract infection. Her cervix was fully dilated and she was complaining of the urge to "bear down." She was afebrile and her amniotic membranes had been artificially ruptured one hour before her request for labour analgesia. Following hydration with $500 \mathrm{ml}$ lactated Ringer's solution iv the patient was placed in the sitting position. The anaesthetist wore a cap, mask, and sterile gloves for the procedure. The lumbar area was prepared using povidone-iodine $10 \%$ spray contained in a spray bottle and draped in a sterile fashion. A disposable epidural tray (Concord/Portex, Keene, NH 03431) was used to perform the block. A \#25 g needle was used to infiltrate the skin with lidocaine $1 \%$ at the $\mathrm{L}_{3-4}$ interspace after which a \#21 g needle was inserted approximately $2 \mathrm{~cm}$ to anaesthetize the deeper structures with the same anaesthetic. A \#17 g Hustead needle was then introduced through the skin into the epidural space using loss of resistance to saline injection with a glass syringe. No cerebrospinal fluid (CSF), or blood was noted at the hub of the needle and the patient did not experience paraesthesia. A disposable \#25 g $12.3 \mathrm{~cm}$ long Quinke spinal needle (Becton/Dickinson Franklin Lakes, NJ 07417) was then passed into the subarachnoid space with the bevel parallel to the dural, fibres using a needle-through-needle technique. There was free flow of clear CSF, and so a mixture of $1 \mathrm{ml}$ bupivacaine $0.25 \%$ from a fresh multidose vial (Abbott Laboratories, North Chicago, IL 60064) and $0.5 \mathrm{ml}(25 \mu \mathrm{g})$ fentanyl (Elkin-Sinns Cherry Hill, NJ 08003) was injected into the subarachnoid space using a disposable plastic syringe. The spinal needle was then withdrawn and an epidural catheter inserted $4 \mathrm{~cm}$ into the epidural space. The catheter was aspirated to check for possible inadvertent subarachnoid or intravenous placement following which a test dose of $3 \mathrm{ml}$ lidocaine $1.5 \%$ with $1: 200,000$ epinephrine was given, which was negative. The patient experienced complete pain relief within two to three minutes.

Four hours after the block she had an uneventful vaginal delivery of a live female infant. The epidural catheter was removed intact one hour after delivery. The site of insertion was without erythema or drainage. Sixteen. hours after delivery her body temperature increased to $38.7^{\circ} \mathrm{C}$, and she complained of a non-positional frontal headache. This was associated with chills, photophobia, and mild nuchal rigidity. No other focal neurological deficits were noted.

Complete blood count was performed which showed a white blood cell (WBC) count of $18.9 \mathrm{k} \cdot \mathrm{mm}^{-3}$ with $87 \%$ polymorphonuclear neutrophils (PMN) and $20 \%$ banded cells with a shift to the left. Urinalysis was normal. Neither urine nor blood cultures were positive for bacterial pathogens. A diagnostic lumbar puncture was performed $25 \mathrm{hr}$ after delivery. The CSF was cloudy. Laboratory analysis of CSF showed a glucose concentration of $29 \mathrm{mg} \cdot \mathrm{dl}^{-1}$ (serum glucose $79 \mathrm{mg} \cdot \mathrm{dl}^{-1}$ ), protein concentration of $190 \mathrm{mg} \cdot \mathrm{dl}^{-1}$ and WBCs of $5800 \cdot \mathrm{mm}^{-3}$ with $82 \% \mathrm{PMN}, 4 \%$ lymphocytes and $12 \%$ monocytes. Gram stain showed $>25$ PMN per highpower field with no bacteria.

An empirical diagnosis of bacterial meningitis was made and antibiotics were started with vancomycin $1 \mathrm{~g}$ every $12 \mathrm{hr}$ and ceftriaxone $2 \mathrm{~g}$ every $8 \mathrm{hr} i v$. The patient was afebrile after $12 \mathrm{hr}$ and asymptomatic by 24 $\mathrm{hr}$. All cultures from the CSF remained negative until 72 hr when a single broth culture grew a possible contaminant, streptococcus salivarius with no bacterial growth on the culture plates. The patient was discharged home on the fifth postpartum day and the $i v$ antibiotics were continued with the help of a visiting nurse until the seventh day. The patient made a total recovery without any neurological sequelae.

\section{Discussion}

Meningitis following regional anaesthesia is rare. A retrospective study of over 500,000 women did not report a single case of meningitis following regional anaesthesia for labour and delivery'. Both bacterial and aseptic meningitis have been reported following spinal and epidural anaesthesia. ${ }^{2-4}$ Only recently, meningitis following a CSE technique was reported. ${ }^{5}$

We believe that our patient had bacterial meningitis because of the low CSF glucose concentration and the predominance of $\mathrm{PMNs}$ in the CSF cytology. ${ }^{6-8}$ However, it is unlikely that the meningitis was caused by the bacteria isolated from the patient's CSF (streptococcus salivarius). This was probably a contaminant because it only grew in a single broth culture, it did not grow on culture plates, and it is not a bacterial pathogen that commonly causes meningitis. Failure to isolate a bacterial pathogen does not disprove a bacterial aetiology because Gram stain and cultures may be negative in up to $10 \%$ of cases of bacterial meningitis. ${ }^{9}$ The serum to CSF glucose concentration ratio in our patient was 0.36 . Briem found a serum to CSF glucose ratio of $<0.4$ to be specific for the diagnosis of bacterial meningitis. ${ }^{8}$ 
The differential diagnosis in our patient includes aseptic meningitis. Aseptic meningitis may be caused by either chemical irritation or a viral infection. ${ }^{10}$ It is characterized by fever, headache, neck stiffness and photophobia. When associated with spinal anaesthesia, it has an acute onset within $24 \mathrm{hr}$ of lumbar puncture. Its course is usually benign and self-limiting. Unlike bacterial meningitis, CSF studies reveal a turbid CSF with an increased CSF WBC count with a predominance of mononuclear cells (lymphocytes). No organisms are seen on Gram stain nor are they grown by conventional culture methods. Protein concentration is elevated but glucose content of the CSF is normal. ${ }^{7}$ The differentiation between bacterial and aseptic meningitis is critical since bacterial meningitis is potentially life-threatening and antibiotic therapy must be started without delay.

Our case bears considerable resemblance to that reported by Lee and Parry. ${ }^{2}$ Their patient developed bacterial meningitis following spinal anaesthesia for caesarean section. In this case no bacteria were seen in the CSF on Gram stain nor were they grown in cultures up to one week later. A diagnosis of bacterial meningitis was made in light of the findings of increased CSF PMN leukocytosis, increased CSF protein and a decreased CSF glucose. ${ }^{2}$ The CSF findings in our patient were nearly identical to those reported by Lee and Parry ${ }^{2}$ who postulated that bacteria were introduced into the subarachnoid space during lumbar puncture despite a meticulous aseptic technique. ${ }^{2}$

Bacterial meningitis has been reported to occur in pregnancy even without the previous use of spinal or epidural anaesthesia. The pathogens probably reach the CNS via the blood stream. Meningitis under these circumstances may be primary or secondary. Primary bacterial meningitis during pregnancy is most frequently caused by $S$. pneumonia and $N$. meningitis, and infrequently by $H$. influenza. ${ }^{11}$ Secondary bacterial meningitis is most commonly associated with infective endocarditis and has an incidence of 1:8000 deliveries. ${ }^{11}$

Harding et al..$^{5}$ reported two cases of meningitis following CSE techniques. The first patient received $25 \mu \mathrm{g}$ fentanyl, bupivacaine $0.25 \% 1 \mathrm{ml}$, and $0.5 \mathrm{ml}$ normal saline intrathecally via a \#27 g Whitacre spinal needle. She also received epidural local anaesthetic during labour and delivery. She began to show neurological signs of meningitis approximately $21 \mathrm{hr}$ after the initial block. Her CSF studies were indicative of aseptic meningitis, but she was treated with antibiotics because a bacterial aetiology could not be ruled out. Harding et al. concluded that this patient had aseptic meningitis secondary to chemical irritation by the injected solution or solutions. Our patient had bacterial meningitis on the basis that she had a much higher CSF WBC count, a lower CSF glucose value, a cloudy CSF, more severe symptoms, and a longer recovery time. The second case involved a CSE technique in which the patient received $25 \mu \mathrm{g}$ fentanyl and $2.5 \mathrm{mg}$ bupivacaine intrathecally using a \#27 $\mathrm{g}$ Whitacre spinal needle. The patient later required Caesarean section at which time the epidural block was inadequate and a single-shot spinal block with hyperbaric bupivacaine was performed using a \#27 g Whitacre spinal needle. The patient developed a post-dural puncture headache three days postoperatively for which she was treated with an epidural blood patch. She began to have signs of meningitis at approximately $14 \mathrm{hr}$ after epidural blood patch. The CSF studies were consistent with bacterial meningitis and Staphylococcus epidermidis was grown in culture. The authors believed this to be a bacterial meningitis secondary to a break in aseptic technique during the epidural blood patch and not secondary to the CSE technique. 5 Our patient developed bacterial meningitis after a combined spinal-epidural technique for labour analgesia and she did not have an epidural blood patch.

A study in bacteraemic rats showed a correlation between bacteraemia at the time of dural puncture and subsequent meningitis. ${ }^{12}$ In rare cases, haematogenous spread may cause meningitis, but this is seldom seen. This may be because development of meningitis requires many steps, only one of which involves the integrity of the meninges. Exactly how bacteria cross from the blood stream into the CSF is not known. Survival of bacteria in the blood stream and CSF, as well as the integrity of the immunological system and the virulence and number of organism involved, are all important factors in the development of meningitis. ${ }^{12}$ Our patient had no signs of localized or generalized sepsis at the time of the anaesthetic procedure. We do not know if the pathogen reached the CSF as a result of primary. haematogenous spread or as a result of a break in the aseptic technique. The pathogen might have been introduced into the CSF by the spinal needle. It is to be noted that the spinal needle did not come in direct contact with the patient's skin. However, it is possible that skin debris could be contained in the epidural needle to be carried later by the spinal needle into the CSF.

We have presented a patient who most probably developed a bacterial meningitis following a CSE technique for labour analgesia. With anaesthetists using CSE techniques for labour analgesia more frequently in up to $90 \%$ of the time in some practices, it is important to be aware of this possible complication. We do not believe that the CSE technique has an increased association with meningitis, but that any spinal/epidural anaesthesia technique may produce this complication. At our institution, we perform approximately 7000 labour and 
delivery anaesthetics per year, of which CSE techniques account for $10 \%$. This is the only case of meningitis that has occurred in our institution. Early diagnosis and treatment are paramount in preventing serious neurological sequelae. We recommend early antibiotic therapy for patients who develop signs and symptoms of meningitis following regional anaesthesia.

\section{References}

1 Scott DB, Hibbard BM. Serious non-fatal complications associated with extradural block in obstetric practice. $\mathrm{Br} \mathrm{J}$ Anaesth 1990; 64: 537-41.

2 Lee JJ, Parry $H$. Bacterial meningitis following spinal anaesthesia for Caesarean section. Br J Anaesth 1991; 66: 383-6.

3 Ready $L B$, Helfer $D$. Bacterial meningitis in parturients after epidural anesthesia. Anesthesiology 1989; 71: 98890.

4 Bert AA, Laasberg LH. Aseptic meningitis following spinal anesthesia - a complication of the past? Anesthesiology 1985; 62: 674-7.

5 Harding SA, Collis RE, Morgan BM. Meningitis after combined spinal-extradural anaesthesia in obstetrics. $\mathrm{Br} \mathrm{J}$ Anaesth 1994; 73: 545-7.

6 Powers WJ. Cerebrospinal fluid lymphocytosis in acute bacterial meningitis. Am J Med 1985; 79: 216-20.

7 Jiao FY, Cao HC, Liu ZY, Wu S, Wong HB. The use of blood glucose/cerebrospinal fluid glucose ratio in the diagnosis of central nervous system infection in infants and children. Journal of the Singapore Paediatric Society 1992; 34: 191-8.

8 Briem $\mathrm{H}$. Comparison between cerebrospinal fluid concentrations of glucose, total protein, chloride, lactate, and total amino acids for the differential diagnosis of patients with meningitis. Scand J Infect Dis 1983; 15: 277-84.

9 Feigin RD, Shackelford PG. Value of repeat lumbar puncture in the differential diagnosis of meningitis. N Engl J Med 1976; 289: 571-4.

10 Marinac JS. Drug- and chemical-induced aseptic meningitis: a review of the literature. Ann Pharmacother 1992; 26: 813-22.

11 Goldstein PJ. Neurological Disorders of Pregnancy. Mount Kisco, NY: Futura Publishing Company, 1986.

12 Carp $H$, Bailey $S$. The association between meningitis and dural puncture in bacteremic rats. Anesthesiology 1992; 76: 739-42. 